\title{
Development of Pop-Up Book Learning Media to Improve Understanding of Teaching
}

\author{
Dwi Lestariningsih \\ Sekolah Tinggi Teologia Injil Abdi Allah, Indonesia \\ Pandi Rais \\ Institut Agama Islam Negeri Kediri, Indonesia \\ Nurdyansyah, Nahdliyah Mutala'liah \\ Universitas Muhammadiyah Sidoarjo, Indonesia
}

\begin{abstract}
Research uses the development of Borg and Gall model development. The product produced in the development of grade 4 pop-up books in elementary schools in Sidoarjo, Indonesia. The results of the development of learning media by the criteria with the results of content expert validation have a $100 \%$ validity percentage. Validation from design experts has a $90 \%$ validity percentage, Validation results from linguists have a $100 \%$ validity percentage, individual results are found $100 \%$, small group trial results are $97.14 \%$, large group trial results are $98.21 \%$. The results of the $t$-test analysis using SPSS 16 with a significance level of 0.05 indicate the p-value of the $t$-test statistic is 0.00, which means (<0.05), it can be concluded that there is a significant significance in the pretest mean values and posttest. This shows the pop-up book learning media developed effectively in increasing students' understanding of Class 4 in Sidoarjo, Indonesia.
\end{abstract}

Keywords: learning media, popo-up book, understanding

\section{INTRODUCTION}

Learning media is a learning process that can be used to increase the motivation and interest of new students in learning activities[1]-[3]. The development of education demands the development of a learning approach. This is in line with the development of student psychology, social dynamics, and the dynamics of the education system in each country that changes[4]-[6].

The use of instructional media will also greatly assist the effectiveness in the delivery of content during learning so that students' understanding and knowledge also increase[7], [8]. and learning media can also support students in the ongoing learning process. For that, the study of Pop Up Book or interactive book as a variant of the media so that teachers do not depend on textbooks that often make students bored and lazy to read books. Teachers, as educators, are vital to realizing national education goals and improving the quality of education in Indonesia. An educator also has responsibility in the classroom to organize and create an atmosphere in the school that supports the teaching and learning process. Teacher and lecturer Law No. 14 of 2005 article 8 states, "the obligation that must be held by teachers is to have academic qualifications, education certification, competence, physically and mentally healthy and can realize national education goals."[9]

Based on these problems, researchers want to develop learning media. Because this Pop Up Book learning media can improve students' competence and learning becomes interactive. because every page of Pop Up Book surprises students, so the atmosphere in the learning process becomes more enjoyable[10], [11]. This refers to the essential competencies students must master to combine media with concepts and contexts related to the school environment. and with this pop-up learning media 
students can explore the potential that is already possessed or that exists in real life as expected that the goal will be achieved.

\section{METHODS}

This study uses the Research and Development model of Barg an Gall [12]. Because this approach is suitable for the development of instructional media. Then the data analysis is obtained from the results of the pre-test, post-test, observation, from the implementation of pop-up books.

\section{RESULTS AND DISCUSSION}

\subsection{Implementation of the pop-up book learning media}

The application of learning media is media as a form and distribution used to convey a message and information. also, as an introductory system, the media, or often called by mediators according to fleming, are the result of interference in the two parties and reconcile[13]-[16]. Whereas Pop-Up Book is a book that has movable parts or has 3D book elements.

Understanding has the meaning of easy to respond, understand, have a long-sighted future, or can also be interpreted as teachings - knowledge which is also referred to as meaningful understanding deepens cognitive and affective functions[14]. In other words, understanding is " mastering " or having the power and ability to take action and having expertise in particular sciences[17].The application of pop-up book media is intended to increase understanding that starts with learning and thinking. Perception is the process, deeds, and ways of understanding. It does not mean that knowledge is not questioned because, to understand, it is necessary to know or know it first.

Natural Sciences deals with how to find out about nature systematically[18], so that science is not only mastering a collection of knowledge in the form of facts, concepts, or principles, but also a process of discovery. Science education is expected to be a place for students to learn themselves and the natural environment. The learning process emphasizes providing direct experience to develop competencies to explore and understand the nature around scientifically. At the elementary school level in Sidoarjo Indonesia, there is an emphasis on learning science, environment, technology, and society, which is directed at teaching experiences to design and create works through the application of science concepts and competence in scientific work wisely.

\section{RESULTS}

In the learning media pop-up book, natural resource materials for elementary school science classes 4 , which have been made, are then validated by content experts, design experts, and linguists.In the first stage, the content expert test was carried out data obtained from the results of structured interviews and questionnaire assessments from content experts. Shows that the percentage of achievement rate is $100 \%$. Are in suitable qualification and appropriate, so the textbooks do not need revision. In the second stage, data were obtained from the Design Expert test through the results of structured interviews and questionnaire assessments from design experts. Shows that the percentage of achievement rate is $90 \%$. They are in a suitable qualification and appropriate, so the textbooks do not need revision.

In the third stage, the linguist test data is obtained through the results of structured interviews and questionnaire assessments from design experts. Shows that the percentage of achievement rate is 
$100 \%$. Are in suitable qualification and appropriate, so the textbooks do not need revision.

\subsubsection{Trials}

The effectiveness test of this learning media is seen from field trials, which are conducted to find out the improvement of students' understanding after learning media is applied. This trial was held on 32-grade students of Sidoarjo Indonesia elementary school with a total of 32 students. And for this trial, students are divided into one individual student, five students into a limited trial, or small groups. Twenty-one students became large group trials.

Figure 1. Pop-Up Book Learning Media

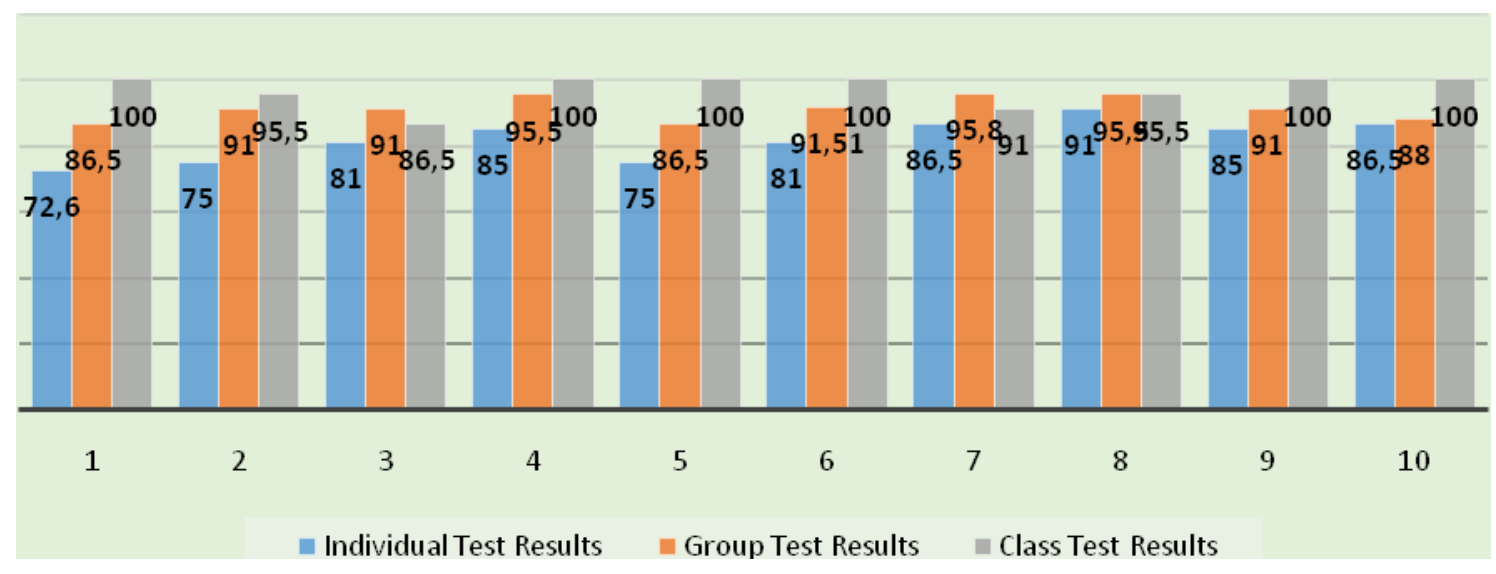

\subsubsection{Feasibility Test}

T Test, Pretest and Posttest Results

Figure 1. Paired Samples Statistics

\begin{tabular}{|lc|c|c|r|r|}
\hline & & & & & Std. Error Mean \\
& & Mean & $\mathbf{N}$ & Std. Deviation & \\
\hline Pair & pretest & 62.5000 & 32 & 18.53158 & 3.27595 \\
1 & posttest & 81.2500 & 32 & 16.12652 & 2.85079 \\
\hline
\end{tabular}

Figure 2.Paired SamplesCorrelation

\begin{tabular}{|ll|l|r|r|}
\hline & & $\mathbf{N}$ & Correlation & Sig. \\
\hline $\begin{array}{l}\text { Pair } \\
1\end{array}$ & Pretest \& Posttest & 32 & .699 & .000 \\
\hline
\end{tabular}


Figure 3.Paired Samples Test

\begin{tabular}{|c|c|c|c|c|c|c|c|c|}
\hline \multirow[t]{3}{*}{ Pair 1} & \multicolumn{5}{|c|}{ Paired Differences } & \multirow{3}{*}{$\mathrm{t}$} & \multirow{3}{*}{$\mathrm{df}$} & \multirow{3}{*}{ Sig. (2tailed) } \\
\hline & \multirow[t]{2}{*}{ Mean } & \multirow[t]{2}{*}{$\mid \begin{array}{l}\text { Std. } \\
\text { Deviati } \\
\text { on }\end{array}$} & \multirow[t]{2}{*}{$\begin{array}{l}\text { Std. } \\
\text { Error } \\
\text { Mean }\end{array}$} & \multicolumn{2}{|c|}{$\begin{array}{c}95 \% \\
\text { Confidence } \\
\text { Interval of } \\
\text { the } \\
\text { Difference }\end{array}$} & & & \\
\hline & & & & Lower & $\begin{array}{l}\text { Upp } \\
\text { er }\end{array}$ & & & \\
\hline $\begin{array}{l}\text { pretest - } \\
\text { posttest }\end{array}$ & $\begin{array}{c}-1.8750 \\
0 \mathrm{E} 1\end{array}$ & $\begin{array}{c}13.6310 \\
8\end{array}$ & 2.40966 & $\begin{array}{c}-23.664 \\
53\end{array}$ & $\mid \begin{array}{c}- \\
13.8 \\
3 \\
547\end{array}$ & -7.781 & 31 & .000 \\
\hline
\end{tabular}

Based on the average or average values in the table above, it can be seen the difference between the results of pretest and protest learning; Pretest results show results with an average value of 62.50, and posttest results show results with an average value of 81.25. Because of the value of $p$ or sig. (2tailed) of 0.00, which means <0.05, it can be concluded that $\mathrm{H} 0$ is rejected and $\mathrm{Ha}$ is accepted. So that means there is a significant influence on the average value of pretest and posttest.

This data shows a significant increase in the average student learning outcomes after receiving different treatments using this Pop-Up Book learning media. Because one of the learning criteria is said to be effective if the student's score or understanding is above the Minimum Mastery Criteria, before using this Pop Up Book teaching media, the pretest results are below the Minimum Mastery Criteria. However, after using this pop-up learning media, the average grade of students becomes above the Minimum Mastery Criteria that have been determined.

From the explanation above, it is explained that the Pop Up Book teaching media about natural resource material is effective when used in learning, because by using this learning media students can become more creative, and student understanding increases.

\subsubsection{Effectiveness Test}

Figure4. Descriptive Statistics

\begin{tabular}{|l|r|r|r|}
\hline & Mean & $\begin{array}{r}\text { Std. } \\
\text { Deviation }\end{array}$ & N \\
\hline HasilBelajar(Posttest) & 81,2500 & 16,12652 & 32 \\
Media & 6,8750 &, 70711 & 32 \\
PembelajaranPop Up & & & \\
Book & & & \\
\hline
\end{tabular}

Based on table 5 illustrates the average value and standard deviation of the value of understanding the posttest (dependent variable) and learning media Pop-Up Book (independent variable). The average value of understanding posttest students was 81.25 , with a standard division of 16.25 . The 
average Pop-Up Book media value applied by researchers is 6.87 , with a standard deviation of 0.5 .

Figure 5 .Model Summary

\begin{tabular}{|l|c|r|c|c|}
\hline Model & $\mathrm{R}$ & RSquare & $\begin{array}{c}\text { Adjusted } \\
\text { R Square }\end{array}$ & $\begin{array}{c}\text { Std. Error of } \\
\text { the Estimate }\end{array}$ \\
\hline 1 &, $127 \mathrm{a}$ &, 016 &,- 017 & 16,25972 \\
\hline \multicolumn{4}{|c|}{ a. Predictors: (Constant), Media Pembelajaran Pop Up } \\
Book \\
\hline \multicolumn{4}{|c|}{} \\
\hline
\end{tabular}

$\mathrm{R}=0.127$ coefficient. Correlation between Pop-Up Book learning media (independent variable) with the results of students' understanding of posttest (dependent variable).

$\mathrm{R}$ square of 0.16 means $16 \%$. This shows that the Pop-Up Book media determine the change in student understanding by $16 \%$. In contrast, the $90 \%$ increase in student understanding is determined by other variables outside the variables in this study. So that interpretation can be made that the PopUp Book media is quite influential on the knowledge of participants in grade 4 learning natural science material natural resources in elementary schools Sidoarjo Indonesia.

\section{CONCLUSION}

Based on the research and development process of the Pop-Up Book learning media on natural resource material for 4th-grade students at the Sidoarjo Indonesia Primary School. First, the feasibility of this Pop-Up Book teaching media can be said to be feasible to use, because the results of product trials can prove it. To find out the feasibility of this product, the researchers conducted an expert testing assessment. The results obtained from the feasibility test for the teaching media of this Pop-Up Book are; a) Validation results from content experts have a 100\% validity percentage, which means the material in the Pop Up Book teaching media is suitable for use. b) The validation results from the design experts have a $90 \%$ validity percentage, which means that the Pop-Up Book teaching media design is valid or suitable for use. c) The validation results from linguists have a $100 \%$ validity percentage, which means the language in the Pop-Up Book learning media is ideal for use.

Second, the effectiveness of Pop-Up Book teaching media is also obtained from students' understanding based on field trials. The results of the t-test analysis of the pretest showed the average value of the pretest results showed an average value of 62.50, and the posttest results showed results with an average value of 81.25 . Because of the value of $\mathrm{p}$ or sig. (2-tailed) of 0.00 , which means $<0.05$, it can be concluded that $\mathrm{H} 0$ is rejected and $\mathrm{Ha}$ is accepted. So that means there is a significant influence on the average value of pretest and posttest. Thus the Pop-Up Book learning media can be said to have good quality. This is because the Pop-Up Book learning media application can facilitate student learning to improve student understanding of science learning.

\section{REFERENCES}

1. P. Zhao, H. Gao, Y. Lu, and T. Wu, "A cross-media heterogeneous transfer learning for preventing over-adaption," Appl. Soft Comput., vol. 85, p. 105819, Dec. 2019.

2. S. Ucus, "Elementary School Teachers' Views on Game-based Learning as a Teaching Method,” Procedia - Soc. Behav. Sci., vol. 186, pp. 401-409, May 2015. 
3. M. B. U. B. Arifin, Nurdyansyah, I. Rindaningsih, and I. Fauji, "Teaching media of fiqh magazine model to improve prayer understanding in primary school students," Univers. J. Educ. Res., vol. 7, no. 8, pp. 1820-1825, 2019.

4. M.-T. Wang, A. Chow, T. Hofkens, and K. Salmela-Aro, "The trajectories of student emotional engagement and school burnout with academic and psychological development: Findings from Finnish adolescents," Learn. Instr., vol. 36, pp. 57-65, Apr. 2015.

5. R. Gairal-Casadó, C. Garcia-Yeste, M. T. Novo-Molinero, and Z. Salvadó-Belarta, "Out of school learning scientific workshops: Stimulating institutionalized Adolescents' educational aspirations," Child. Youth Serv. Rev., vol. 103, pp. 116-126, Aug. 2019.

6. S.-C. Chang and G.-J. Hwang, "Impacts of an augmented reality-based flipped learning guiding approach on students' scientific project performance and perceptions," Comput. Educ., vol. 125, pp. 226-239, Oct. 2018.

7. V. Sahasrabudhe and S. Kanungo, "Appropriate media choice for e-learning effectiveness: Role of learning domain and learning style," Comput. Educ., vol. 76, pp. 237-249, Jul. 2014.

8. J. Y. Wu, "The indirect relationship of media multitasking self-efficacy on learning performance within the personal learning environment: Implications from the mechanism of perceived attention problems and self-regulation strategies," Comput. Educ., vol. 106, pp. 56-72, 2017.

9. U.-U. R. Indonesia, “Tentang Guru Dan Dosen Nomor 14 Tahun 2005,” 2005, p. 8.

10. Y. T. Lee, S. B. Tor, and E. L. Soo, "Mathematical modelling and simulation of pop-up books," Comput. Graph., vol. 20, no. 1, pp. 21-31, Jan. 1996.

11. D. R. A. Rambli, W. Matcha, and S. Sulaiman, "Fun Learning with AR Alphabet Book for Preschool Children," Procedia Comput. Sci., vol. 25, pp. 211-219, Jan. 2013.

12. W. B. M. D. Gall, Educational Research an Introduction. New York: Logman, 1983.

13. S. De Freitas and M. Griffiths, "The convergence of gaming practices with other media forms: What potential for learning? A review of the literature," Learn. Media Technol., vol. 33, no. 1, pp. 11-20, 2008.

14. M. Chen, "Children and families in the digital age: learning together in a media saturated world," J. Child. Media, pp. 1-4, 2019.

15. I. Stanley, A. al-Shehri, and P. Thomas, "Continuing education for general practice. 1. Experience, competence and the media of self-directed learning for established general practitioners.," Br. J. Gen. Pract., vol. 43, no. 370, pp. 210-4, May 1993.

16. S. Chotimah, M. Bernard, and S. M. Wulandari, "Contextual approach using VBA learning media to improve students' mathematical displacement and disposition ability," J. Phys. Conf. Ser., vol. 948, no. 1, 2018.

17. F. Agustiya et al., "Influence of CTL Model by Using Monopoly Game Media to The Students' Motivation and Science Learning Outcomes," J. Prim. Educ., vol. 6, no. 2, pp. 114119, 2017.

18. A. Arroio, "Context Based Learning: A Role for Cinema in Science Education.," Sci. Educ. Int., vol. 21, no. 3, pp. 131-143, 2010. 